\title{
Política e forma literária no último quartel do século $X X$
}

\author{
Politics and Literary Form in the Last Quarter of the Twentieth Century \\ Política y forma literaria en el último cuarto del siglo $X X$
}

Benedito Antunes

\section{Resumo}

Neste artigo são analisados Um copo de cólera (1978), de Raduan Nassar, e Estorvo (1991), de Chico Buarque, com a finalidade de se observar a possível relação entre a forma romanesca e os conflitos políticos do último quartel do século XX no Brasil. Parte-se da hipótese de que os elementos evocados nos livros configuram literariamente um impasse que remete ao contexto externo, permitindo, nesse movimento, uma percepção estética desse período. Trata-se, portanto, de uma tentativa de leitura dialética, nos moldes formulados por Antonio Candido e Roberto Schwarz, em que se procura aproximar a forma social da forma literária visando estabelecer perspectivas de compreensão tanto de uma quanto de outra. Como resultado, a análise sugere um processo de desnorteamento na luta pela transformação social.

Palavras-chave: romance brasileiro contemporâneo, Raduan Nassar, Chico Buarque, literatura e história.

Abstract

This paper analyses Um copo de cólera (1978), by Raduan Nassar, and Estorvo (1991), by Chico Buarque, aiming to observe the possible relationship between Romanesque form and political conflicts of the last quarter of the $20^{\text {th }}$ century in Brazil. The paper hypothesizes that the elements recalled in the books literarily reach a deadlock which refers to an external context, gaining, in that movement, an esthetical perception of the period. Therefore, it is a dialectic reading attempt, in the same way proposed by Antonio Candido and Robert Schwartz, in which one tries to approximate the social form to the literary one, aiming at establishing perspectives of understanding, as much for one as for the other. As a result, the analysis suggests a process of disorientation in the quest for social transformation.

Keywords: Contemporary Brazilian novel, Raduan Nassar, Chico Buarque, literature and history.

\section{Resumen}

Este artículo analiza Um copo de cólera (1978), de Raduan Nassar, y Estorvo (1991), de Chico Buarque, con el objetivo de observar la posible relación entre la forma novelística y los conflictos políticos del último cuarto del siglo XX en Brasil. Uno propone la hipótesis de que los elementos recordados en los libros alcanzan literalmente un punto muerto que se refiere a un contexto externo, obteniendo, en ese movimiento, una percepción estética de ese período. Por lo tanto, es un intento de lectura dialéctica, de la misma manera propuesta por Antonio Candido y Robert Schwartz, en el que se trata de aproximar la forma social a la literaria con el objetivo de establecer una perspectiva de comprensión tanto para uno como para otro. Como resultado, el análisis sugiere un proceso de desconcierto en la búsqueda de la transformación social.

Palabras-clave: novela brasileña contemporánea, Raduan Nassar, Chico Buarque, literatura e historia.

Não se sabe quando e como será descrita de modo equilibrado e profundo a situação política vivida pelo Brasil nas primeiras décadas do século XXI. É possível supor, porém, que caberá ao romance grande parte da tarefa de abordar as incertezas e os desafios desse período. A forte polarização ideológica, própria de momentos críticos do ponto de vista político, não favorece discussões abertas nem análises aceitáveis pelas tendências em confronto. Assim, é provável

\footnotetext{
*Universidade Estadual Paulista (Unesp), Assis, SP, Brasil. (Dorcid.org/0000-0001-8269-4410. E-mail: benedito.antunes@unesp.br
} 
que a forma literária, devido à sua natureza plurissignificativa, surja como alternativa de representação desses conflitos, sugerindo, se não sua a compreensão, pelo menos as linhas gerais de seu equacionamento.

É sob essa perspectiva que se pretende observar como dois livros de relativa importância na literatura brasileira contemporânea abordaram temas políticos do último quartel do século $\mathrm{XX}$, no contexto de uma ditadura militar que se estendeu por mais de vinte anos. Considera-se que, de alguma maneira, a representação proposta por esses livros pode lançar luz também sobre a vida política posterior, pois, a rigor, as contradições e as dificuldades para seu enfrentamento naquele momento permanecem essencialmente as mesmas. Trata-se de Um copo de cólera (1978), de Raduan Nassar, e Estorvo (1991), de Chico Buarque, romances que comportam traços típicos da contemporaneidade, constituindo uma modalidade de narrativa que aborda questões sociais e políticas complexas de modo nem sempre direto, como ocorria no romance realista típico. Experimentam, assim, uma espécie de impasse formal, não dissociado do plano temático, que remete a um possível impasse no contexto representado.

As palavras cólera e estorvo, tomadas isoladamente, estão longe de evocar algo agradável. Dada a sua natureza abstrata, remetem a sentimento ou condição de um determinado ser e podem, no caso de personagem literária, estender-se ao próprio ouvinte ou leitor, tornando-se para eles fonte de desconforto. Cólera implica violenta oposição, raiva intensa, ira, enfim, configurando, portanto, uma atitude de indignação ou revolta do sujeito que lhe confere existência. Já estorvo, se aplicada a um ser humano, parece sugerir atitude oposta, por impedir ou embaraçar a realização de algo. Assim, observa-se, num caso, indignação e revolta, noutro, resignação e embaraço. Em suma, explosão e passividade caracterizariam comportamentos de indivíduos conforme sejam associados a um ou outro termo. Aparentemente opostas, essas condições guardam, porém, uma base comum: a irracionalidade de um movimento circular cujo efeito se volta para o próprio indivíduo, revelando-se inútil do ponto de vista prático, mas podendo, por outro lado, desdobrar-se em outros efeitos, igualmente desagradáveis ou incômodos. Com essas conjecturas sobre os vocábulos "cólera" e "estorvo", pretende-se antecipar a linha da análise aqui empreendida, que se baseia na percepção de que os títulos já indicam a complexidade e o sentido profundo do enredo dos livros.

A orientação teórica para a análise proposta filia-se aos princípios defendidos, entre outros, por Theodor Adorno, que aponta o paradoxo do romance contemporâneo na impossibilidade de narrar, "ao passo que a forma do romance exige a narração" (1980, p. 269). Assim, a alternativa para esse gênero seria "concentrar-se naquilo de que o relato não dá conta", renunciando a um realismo de fachada e buscando criar uma forma que, enquanto tal, configure os impasses da sociedade reificada. Essa opção estética esbarraria, porém, na própria linguagem, que constrange o romance à ficção do relato, o que leva Adorno a valorizar o procedimento de um James Joyce quando este vincula "a rebelião do romance contra o realismo a uma rebelião contra a linguagem discursiva" (1980, p. 269).

Tal perspectiva, embora voltada para o estudo do romance contemporâneo, tem o mérito de ampliar a compreensão da forma literária e pode ser aproximada do método dialético desenvolvido por Antonio Candido, que articula "invenção formal" e "apreensão histórica" para usar os termos da síntese feita por Roberto Schwarz (2012, p. 48). Segundo esse método, "não é a representação dos dados concretos particulares que produz na ficção o senso da realidade; mas, sim, a sugestão de certa generalidade, que olha para os dois lados e dá consistência tanto aos dados particulares do real quanto aos dados particulares do mundo fictício" (Candido, 1993, p. 45). Nesse processo, conforme explica Schwarz, "a forma - que não é evidente e que cabe à crítica identificar e estudar - seria um princípio ordenador individual, que tanto regula um universo imaginário como um aspecto da realidade exterior". Essa forma combina - ainda nas palavras de Schwarz - "a fabricação artística e a intuição de ritmos sociais preexistentes" (2012, p. 48). À crítica caberia "explicar como configurações externas, pertencentes à vida extra-artística, podiam passar para dentro de obras de fantasia" (2012, p. 48), integrando a estrutura da obra literária e revelando sentidos ocultos à primeira vista que, uma vez compreendidos, resultam em conhecimento novo nos dois campos. Embora de 
validade abrangente, o método parece aplicar-se com maior propriedade às obras que buscam a "emancipação do objeto", conforme os termos de Adorno (1980, p. 269).

Para a análise dos romances, foi considerada ainda a hipótese de que eles, cada um à sua maneira, representariam o desdobramento de uma linha de força observada ao longo do desenvolvimento do gênero no Brasil e que receberia contornos mais fortes no século XX, particularmente após os anos 1930, quando as contradições sociais se tornaram mais evidentes em diversos níveis, com várias implicações no plano político. Nesse sentido, os dois livros podem ser lidos numa sequência que passaria, entre outros, por S. Bernardo (1934), de Graciliano Ramos. Nesse romance, uma das mais agudas representações do impasse narrativo diante das contradições da sociedade burguesa, cabe ao narrador concentrar todos os elementos mobilizados no universo ficcional. Sua condição de personagem empreendedora, quase uma alegoria do próprio capitalismo, adquire maior relevância ao se tornar o memorialista que procura refletir sobre sua vida com a finalidade de compreendê-la. Essa compreensão pressupunha a compreensão de sua esposa, Madalena, que resiste até à morte ao universo reificado da propriedade do marido. Mas o narrador chega ao impasse por não atingir plenamente seus objetivos no plano da fabulação, e sua narração começa a girar em falso, representando, com isso, a própria essência de seu drama, que se estenderia, por analogia formal, ao contexto externo da obra.

Os romances de Raduan Nassar e de Chico Buarque, produzidos a partir da década de 1970, parecem representar uma etapa posterior da história social e política brasileira, em que se observam um acirramento das contradições sociais e uma provável complicação das condições de resistência à reificação, o que é indicado pelo aumento da dificuldade de narrar. Nesse quadro, os livros encenariam a ação descontrolada ou a própria falta de ação, configurando, depois de momentos de intensa conturbação e revolta nos anos 1960 e 1970, a perturbadora acomodação do fim do século XX. Com efeito, observa-se neles, mais do que a representação direta da resistência política, o possível rescaldo de seu insucesso, com a ausência de alternativas num contexto em que restariam poucas ilusões quanto à luta pela transformação social.

\section{Cólera}

Antes de tratar de seu livro, vale recordar que Raduan Nassar (1935-) é um dos escritores mais curiosos da literatura brasileira contemporânea. Por dois motivos: i) escreveu pouco; e ii) abandonou a carreira no auge da fama. Sob certos aspectos, os dois motivos estão interligados, pois sua obra foi logo reconhecida pela qualidade literária e seu afastamento do mundo literário foi justificado, ao menos em parte, pelo propósito de não diluir o que já havia escrito. É o que se pode concluir de uma explicação que ele próprio forneceu para sua decisão. Apossando-se da frase de Otto Rank, enviada por seu amigo José Carlos Abatte quando ele parou de escrever, declarou na entrevista à edição dos Cadernos de Literatura Brasileira a ele dedicada: "Desisti de escrever porque há um excesso de verdade no mundo" (Nassar, 1996, p. 24).

Sua obra é constituída de Lavoura arcaica (1975), Um copo de cólera (1978) e Menina a caminho (1994). Os três livros foram escritos quase simultaneamente, o que contribui para caracterizar um projeto literário um tanto fechado, sem diálogo com a crítica, como ele mesmo admite. Provavelmente por isso, todos têm uma base comum, não tanto no âmbito da temática, que varia de um para outro livro, mas na atitude do narrador, que representa a impostação do escritor diante da vida: propugna uma "rejeição a tudo que está aí" (Nassar, 1996, p. 32), como diz na entrevista mencionada. E é provável que a formalização dessa rejeição se apresente de modo mais cabal justamente em Um copo de cólera.

O primeiro aspecto que chama a atenção no livro é sua brevidade. São 77 páginas distribuídas em sete capítulos, se é que podem ser denominados assim, principalmente porque há um acentuado desequilíbrio entre eles: quase todos têm entre três e seis páginas ("A chegada", "Na cama", “O levantar", "O banho", "O café da manhã" e novamente "A chegada"), com exceção do principal deles, "O esporro", que tem 54 páginas. Os sete capítulos correspondem, na verdade, a sete parágrafos, com apenas um ponto final. Assim, um dos 
parágrafos, justamente o dedicado a "O esporro" (sexto capítulo), ocupa cerca de 70\% do livro. E isso tem, evidentemente, um sentido, como se procurará demonstrar a seguir.

Com tais características aparentes, o livro suscita uma primeira questão: como ele poderia ser classificado? Conto, novela ou romance? Em nomenclatura clássica, seria um conto, pela extensão, uma novela, e pela ficha catalográfica, um romance - denominação aqui adotada. Isso porque a densidade da história ultrapassa o nó de um conto e se acomoda mal na estrutura convencional de uma novela. Além do mais, o romance, enquanto gênero clássico, teve seu fim decretado no início do século XX, de modo que, de lá para cá, tudo pode ou não ser romance. A favor dessa hipótese, toma-se como referência o já citado S. Bernardo, de Graciliano Ramos, que apenas na aparência corresponde ao modelo canônico do gênero. Esse livro, como se sabe, comporta, por meio da metalinguagem, uma ampla discussão de romance, sugerindo que a temática não cabe em sua estrutura tradicional. Aliás, a menção a $S$. Bernardo, feita aqui pela segunda vez, não é casual. Raduan Nassar admitiu na citada entrevista que, entre outros, o romances S. Bernardo, de Graciliano Ramos, faz parte de seus "afetos" (Nassar, 1996, p. 30).

Analogamente à sua brevidade, a obra tem um enredo mínimo, quase rarefeito. O narrador chega a sua chácara, onde a companheira já o esperava. Os dois mantêm um tórrido encontro amoroso, dormem, levantam-se, tomam banho e, durante o café da manhã, ele percebe que as saúvas fizeram um rombo na cerca viva de ligustro. Fica enfurecido e inicia um longo e violento desabafo, fazendo da companheira uma espécie de deuteragonista, cujas intervenções, reproduzidas por ele, servem, sobretudo, para aumentar sua fúria, que evolui até a agressão física. Ela vai embora e retorna em outro momento, quando tudo recomeça, com a chegada à chácara narrada de sua perspectiva.

Embora simples, o enredo tem inúmeras implicações, todas decorrentes da esmerada arquitetura narrativa, em que o narrador ocupa o centro do proscênio. $O$ principal interesse, por isso, reside justamente na voz que narra. Nesse sentido, observa-se que o tom do capítulo central "O esporro" - percorre todo o livro, que é tenso da primeira à ultima página. Basta examinar o brevíssimo primeiro capítulo para se ter uma ideia do restante quanto a esse aspecto. Narrado como os demais em primeira pessoa, quase não traz diálogos além de um "O que que você tem?" dela, que fica sem resposta, e do "Você já jantou?" dele, respondido com um sincopado "Mais tarde". No mais, são negaceios que conduzem ao encontro amoroso, em que parece não haver afeto nem cordialidade, mas apenas gestos ensaiados de rotina que precedem a relação sexual. A rigor, esta não chega a ser apresentada, uma vez que é antecipada pela recordação de práticas anteriores enquanto o narrador espera pela mulher que entrara no banheiro. Tanto que, quando ela volta para o quarto, há um corte e o ato fica apenas sugerido na imaginação dele. Em todo caso, no capítulo seguinte, o homem está saciado e constata que a mulher apresenta "um visgo grosso e de cheiro forte por todo o corpo" (Nassar, 1992, p. 18), confirmando a intensidade da relação. Voltando ao clima da cena, a própria maneira como ele antes cortara e comera o tomate, somada ao silêncio dos dois, constitui uma provocação tácita, concentrada nos aspectos ligados à sensualidade, que prepara a tensão, e talvez um pouco da brutalidade que marca o encontro do casal na cama e principalmente o embate no quintal logo depois.

A focalização, tanto nas cenas iniciais como de resto em todo o romance, funciona à maneira de uma câmera que acompanha os movimentos do casal, sempre do ângulo dele: "parecíamos dois estranhos que seriam observados por alguém, e este alguém éramos sempre eu e ela, cabendo aos dois ficar de olho no que eu ia fazendo, e não no que ela ia fazendo" (Nassar, 1992, p. 12). Trata-se de uma descrição externa, já que o narrador não adota a tradicional perspectiva onisciente, embora observe atentamente o que a companheira faz e talvez pense, revelando que a conhece bem. Isso the permite assumir uma pose estudada, quase teatral: "e eu, sempre fingindo, sabia que tudo aquilo era verdadeiro, conhecendo, como conhecia, esse seu pesadelo obsessivo por uns pés" (Nassar, 1992, p. 13). Na cena da cama, os dois revelam igualmente que se conhecem nos detalhes da intimidade. Mas essa familiaridade vai sendo pontuada com notações estranhas, que reforçam a tensão do momento: “[...] e eu daí entrei pensando nos momentos de renovação, nos cigarros que fumávamos seguindo a cada bolha envenenada de silêncio" (Nassar, 1992, p. 16). 
Com essas observações, o narrador, que um pouco antes se considerara torpe, sórdido e canalha na relação, vai-se revelando poderoso e demonstrando "segurança e ousadia na condução do ritual", enquanto a inteligência dela é considerada, com certo menosprezo, "sua melhor qualidade na cama" (Nassar, 1992, p. 16). Um dos possíveis efeitos do processo narrativo é a representação da relação amorosa entre eles como um jogo que simula táticas de guerrilha ao confrontar caracteres, sentimentos e ideias. Alberto Sismondini reforça essa percepção ao considerar o bate-boca que se seguirá: "uma guerra verbal durante a qual os respectivos pressupostos ontológicos, construídos em cima de palavras, vão sendo demolidos reciprocamente" (2017, p. 110). O mesmo tom continua depois, na descrição do banho, em que ele é tratado como uma criança cuidada pela mãe, embora seja ele a conduzir o jogo: "eu só sei que me entregava inteiramente em suas mãos pra que fosse completo o uso que ela fizesse do meu corpo" (Nassar, 1992, p. 24).

Dessa maneira, os cinco capítulos iniciais funcionam como um preâmbulo à cena central, neles prevalecendo, de um lado, a caracterização das personagens (incluindo os caseiros) e do espaço e, de outro, da relação entre os dois amantes, configurando o clima tenso, em parte simbólico, que vai dominar "O esporro". O espaço é exíguo e corresponde a uma espécie de palco teatral. Limitado ao interior da propriedade, configura diferentes cenários: a entrada da chácara, o interior da casa e o quintal, onde ocorre o ápice da encenação. Do ponto de vista temporal, observa-se que os acontecimentos transcorrem em menos de 24 horas, mas parecem durar muito mais, porque se desenvolvem à maneira de uma cena teatral, que pressupõe um tempo anterior e outro posterior, configurados pelas personagens no processo de encenação. Estas, por sua vez, dividem-se em pelo menos dois grupos: um secundário, formado pelos empregados da chácara, Dona Mariana e Seu Antônio, que são dotados de nomes e papéis definidos, enquanto o outro compreende os atores principais da história, cujos nomes não são pronunciados e suas ocupações são apenas sugeridas. Assim, o maior interesse reside na caracterização dessas personagens na própria cena. Suas falas, repletas de subentendidos, logram antes expressar sua condição e o contexto em que vivem do que representar fatos efetivamente protagonizados por elas.

Os episódios, em seu conjunto, parecem narrados à maneira de sequências cinematográficas: i) a chegada dele; ii) o encontro amoroso; iii) o banho; iv) o café da manhã; v) a discussão; e vi) a chegada dela. Conforme se observou anteriormente, todas as tomadas concorrem para a cena da discussão - uma longa sequência sem cortes -, que se dá no espaço aberto do quintal e tem os caseiros como plateia. Dado o motivo aparente dessa discussão - a destruição da cerca viva pelas saúvas -, cria-se a sugestão de que a fúria da personagem deve-se menos aos eventuais prejuízos materiais do que à abertura criada pelas formigas, que coloca em comunicação o ambiente recolhido da chácara e o mundo externo, de conotações ameaçadoras.

Em suma, a história consiste no encontro aparentemente rotineiro de um casal, perturbado nesse dia pela irritação do homem com a destruição da cerca e que não aceita a censura da mulher à sua reação violenta e ao tratamento grosseiro que ele dispensa à caseira quando começa a combater as formigas. Mas esse motivo é frágil para justificar seu comportamento: "[...] não é pra tanto, mocinho que usa a razão" (Nassar, 1992, p. 33), provoca ela. Tudo indica, assim, que a irritação estivesse à flor da pele, esperando um pretexto para explodir. Não se trata, portanto, de uma briga casual; configura-se na cena um conflito que extrapola os aspectos afetivos dos dois e envolve o clima social e político vivido ou percebido por eles. Assim, a chácara em que se isolam, mais do que um mero local para encontros amorosos, pode configurar o microcosmo de um universo maior, cujas contradições movem o relacionamento do casal.

Nesse quadro, avulta a ambiguidade da figura do narrador, que, no recomeço da história, parece perder a condição de alguém que tudo controla e passa a ser visto pela perspectiva dela. Consequência: coerentemente com a cena teatral, ele se anula enquanto ser consciente de seu relato, mas se torna pleno de sentido porque tudo é dado pela sua voz, no momento da enunciação. Esses aspectos da narrativa configuram, mais do que uma história narrada, uma atitude, que resulta não tanto de ações, mas de um sentimento de revolta, de uma explosão biliosa e irascível. 
Retomando-se a sequência do encontro amoroso ("Na cama"), percebe-se que ela antecipa o clima da explosão, não por acaso narrada na sequência intitulada "O esporro". Naquela, os elementos sensuais vão adquirindo contornos cada vez mais tensos, observados desde a chegada do homem à chácara, num suspense que parece preparar o casal para o confronto. Logo, o conflito adquire uma dimensão ampla e aponta para outro sentido, que o título do livro sugere com ênfase: um copo de cólera. A esse propósito, vale observar que a palavra cólera, ao compor a expressão do título, transita de sua natureza abstrata para algo concreto, como um líquido que pudesse ser ingerido. Assim, o sentido próprio de ira, fúria, ou ímpeto, dada a contundência da reação da personagem, expande-se para uma espécie de personificação da revolta. É como se, enfurecido com as formigas que cortam as plantas e destroem sua cerca, o homem se impregnasse do veneno que usa para combatê-las: "[...] aproveitei a provisão das prateleiras pra me abastecer de outros venenos, além de eu mesmo, na rusticidade daquele camarim, entre pinceis, carvão e restos de tinta, me embriagar às escondidas num galão de ácido, preocupado que estava em maquinar por dentro as minhas vísceras" (Nassar, 1992, p. 33).

Assim envenenado, passa a agir sob o efeito "duma virulenta congestão, co'as coisas fermentadas na panela do [seu] estômago" (Nassar, 1992, p. 43). Esporro, nesse contexto, constitui uma imagem forte, que parte da referência sexual e atinge um nível mais amplo de expressão. Tanto que entre uma bofetada e outra raciocina: "(seria sim no esporro e na porrada!)" (Nassar, 1992, p. 69).

Descrito o processo, é preciso buscar compreender o sentido dessa explosão. Embora Raduan Nassar tenha mencionado a leitura de alguns livros de Robbe-Grillet (Nassar, 1996, p. 35), não admite claramente a influência do nouveau roman em sua criação. Isso não impede que a crítica aproxime Um copo de cólera de La jalousie, do escritor francês, não apenas por causa do processo narrativo, com minuciosas sequências descritivas, como também pelo fato de uma personagem da fazenda tratar a plantação de bananeiras com inseticida para proteção contra cupins (Sismondini, 2017, p. 131). Coincidência ou não, a verdade é que, em Nassar, a construção tem outras finalidades. Já que o narrador não assume o papel de quem conhece e conta uma história, mas se apresenta de forma impetuosa, portanto não confiável, cabe observálo. E, mais ainda, observar em detalhes seu discurso, pois é dele que surge todo o resto: sua caracterização e a de sua companheira, seu modo de vida, seus valores e suas crises.

Aparentemente, ele é um proprietário, que vive de renda, pois sua profissão não é explicitada. Na discussão, ela o tacha de "biscateiro graduado" (Nassar, 1992, p. 45), para mais adiante atirarlhe a suspeita de "falsário", que o obriga a desconversar, "não permitindo que ela sopesasse a gravidade da suposta descoberta" (Nassar, 1992, p. 57). A mulher, por sua vez, é jornalista, de esquerda, com tendências feministas, que denuncia ações da ditadura e se preocupa com os oprimidos. Por isso, considera fascista o comportamento do companheiro, tanto no episódio vivido no presente quanto em suas atitudes em geral. Não há, porém, indícios de que ele seja, digamos, de direita, e se contraponha a ela como um proprietário. Os xingamentos que lhe dirige e as atribuições de natureza política que lhe faz revelam não apenas o conhecimento de causa - ele domina os meandros do discurso político -, como parecem atingir a ele próprio, fazendo doer sua consciência de provável homem de esquerda em crise, que se retirou do convívio social por não acreditar em mais nada: "não aceito pois nem a pocilga que está aí, nem outra 'ordem' que se instale" (Nassar, 1992, p. 62). Com efeito, nos inúmeros ataques que faz à companheira, percebe-se um desconforto pela sua omissão. De um lado, ele aponta nela diversas contradições, como a hipocrisia de defender o povo e, ao mesmo tempo, fazer-se servir: "[...] tagarelando tão democraticamente com gente do povo, que era por sinal uma das suas ornamentações prediletas, justamente ela que nunca dava o ar da sua graça nas áreas de serviço lá da casa" (Nassar, 1992, p. 32). Mais adiante, faz referências aos intelectuais que seriam seus modelos ideológicos de forma depreciativa, como "tábuas dos seus ídolos", "altar dos dogmas", sintetizando sua atuação como uma fantasia: "[...] e tem que isso me leva a pensar que dogmatismo, caricatura e deboche são coisas que muitas vezes andam juntas, e que os privilegiados como você, fantasiados de povo, me parecem em geral como travesti de carnaval" (Nassar, 1992, p. 50). De outro lado, diante da posição secundária da mulher no palco, que tem suas falas filtradas pela reprodução do 
companheiro, parece que o homem fala consigo próprio, como num grande desabafo. Aliás, encolerizar-se tem muito de sofrimento, de patológico, também no sentido psicológico, pois quem sente cólera torna-se sujeito e objeto da ação.

Nesse sentido, um aspecto que se destaca no embate do casal é a experiência maior do homem, que lhe permitiria talvez maior distanciamento crítico, ou mesmo desencanto. Enquanto chama a mulher de jovenzinha e "jornalistinha de merda", ele próprio se considera velho: "[...] a jovenzinha nunca tinha o bastante deste 'grisalho'" (Nassar, 1992, p. 54). A certa altura proclama: "já foi o tempo em que reconhecia a existência escandalosa de imaginados valores" (Nassar, 1992, p. 54). Essa atitude é reiterada nas seguintes passagens:

[...] me sinto hoje desobrigado, é certo que teria preferido o fardo do compromisso ao fardo da liberdade; não tive escolha, fui escolhido, e, se de um lado me revelaram o destino, o destino de outro se encarregou de me revelar: não respondo absolutamente por nada, já não sou dono dos meus próprios passos (Nassar, 1992, p. 57-8).

[...] já disse que a margem foi um dia meu tormento, a margem agora é a minha graça, rechaçado quando quis participar, o mundo hoje que se estrepe! caiam cidades, sofram povos, cesse a liberdade e a vida (Nassar, 1992, p. 59).

[...] que tudo venha abaixo, eu estarei de costas (Nassar, 1992, p. 60).

Há nessas passagens um desabafo mais organizado, mas a manifestação de descontentamento perpassa todo seu longo discurso, configurando, assim, a representação de um drama mais profundo do que a aparente crise entre dois amantes: um drama externo a eles que, pelos indícios apresentados, remeteria à opressão política e às possíveis tentativas de resistência a ela, da qual ele abdicou. ${ }^{1}$ Nesse sentido, deparar com a invasão das formigas, que trabalham à noite, de forma ordeira e eficiente, rompendo a cerca que separa a chácara do espaço externo, representa para o homem um ato de violência, que ameaça, mais do que a propriedade, o seu refúgio, que lhe proporciona o desejável afastamento do universo social. $\mathrm{O}$ rompimento da separação entre o refúgio do homem e o mundo externo pela destruição da cerca gera a explosão com a mulher, porque, na verdade, é uma metáfora da invasão que esta provoca ao manter o relacionamento com ele. Tanto que, após entupir os olhos dos formigueiros com veneno, ele vai até a prateleira para se "abastecer de outros venenos", para calar a companheira com uma retórica envenenada que culmina com duas bofetadas.

Com efeito, as divergências do casal vão além de possíveis conflitos no plano pessoal ou em sua experiência de vida; atinge muito mais a maneira de se contrapor ao universo exterior que os sufoca. É possível perceber, em vários momentos da explosão dele, uma crítica implícita à provável limitação de uma luta política que resulte numa nova organização social, igualmente insatisfatória. Afinal, o engajamento político da mulher, que manifestando firme contestação da ordem vigente, parece acusar a passividade dele. Observa-se, porém, que essa divergência não chega à ruptura do relacionamento; pelo contrário, após o clímax da cólera, ele fica prostrado, sendo amparado pelos dois empregados, e, no recomeço da história, sua fragilidade é tal que a mulher, ao chegar novamente à chácara, tem o desejo de acolhê-lo no útero, criando uma circularidade de sentimento que se identifica com a própria circularidade da narrativa. $\mathrm{Na}$ verdade, a mudança de perspectiva (real ou imaginada, o que dá no mesmo) permite incluir a figura do homem na da mulher. A imagem da volta ao útero é forte, pois, assim como a mulher está no interior do homem durante a explosão deste (é ele que a representa e reproduz sua voz), o homem virtualmente figura aqui no interior da mulher, sugerindo uma interação que acentua um sentimento poderoso de repulsa e atração, que se resolve em cólera.

Seja na forma circular da narrativa (ou espiral, como preferiria o autor), seja nessa espécie de nascimento ao contrário, o percurso do narrador configura um giro em falso, isto é, não movimenta as personagens, que retornam ao ponto de partida, sem perspectiva de avançar.

\footnotetext{
${ }^{1}$ Pode também, implicitamente, projetar no futuro uma perspectiva otimista. Thayse L. Lima, que dedica um longo estudo ao desencanto na obra do autor, chega a aventar que a fúria do narrador "escondia, na verdade, o desejo por uma ordem verdadeira, algo que se revela impossível na sociedade" (2006, p. 101).
} 
Seria a representação da impotência diante de algo mais forte, cujo enfrentamento não é viável, a não ser por um imenso grito colérico, que atinge fundamentalmente quem grita. Tanto que o narrador sugere que a cólera pode ser "o melhor alívio da culpa" (Nassar, 1992, p. 44).

A falta de clareza e de contornos bem definidos das personagens e a própria ausência de ações consequentes, uma vez que tudo é vivido num tempo interior descrito pelo narrador, sugerem, assim, um beco sem saída, que atinge o leitor e o contamina menos por aquilo que é dito racionalmente do que por aquilo que o faz experimentar por uma espécie de imagem mental que, de alguma forma, também o encoleriza. Isto é, sem dúvida, muito mais eficaz, do ponto de vista narrativo, do que uma história construída pelo relato bem estruturado e corente dos fatos implícitos no encontro do casal, o que soaria algo ingênuo e pouco realista enquanto representação, principalmente porque pressupõe uma consciência narradora improvável em relação ao contexto social evocado. Seria como assistir à encenação de um drama num palco italiano, com a proteção da distância temporal e do enquadramento espacial, em que tudo fosse controlado por uma narração objetiva dos fatos. No caso do romance, o leitor encontra-se tão mergulhado no drama que é provável que, mais do que assistir à narração de uma história, experimente os eflúvios lançados pelo narrador. Talvez por isso, Leyla Perrone-Moisés tenha situado Um copo de cólera "longe dos estereótipos da literatura engajada", afirmando que se observa no livro "a insidiosa contaminação das relações individuais pelo discurso do poder, o discurso fascista", e por isso ele "reflete bem a situação vivida pelos brasileiros sob a ditadura militar" (Perrone-Moisés, 1996, p. 69). Essa observação sublinha a natureza do romance, que foge ao modelo convencional de narrativa e opta pela linguagem como forma de realismo.

\section{Estorvo}

Estorvo, por sua vez, parece ambientado no período posterior à ditadura militar que governou o Brasil de 1964 a 1984 e, nesse sentido, talvez represente o pleno desencanto com o sonho de mudanças radicais, condizente com o espírito de 1968. Trata-se de uma narrativa simples, mas consistente, capaz de provocar forte efeito no leitor que acompanha o que o narrador-personagem faz, vê ou imagina. Os fatos narrados são um tanto estranhos, porque inconclusos, como se nada tivesse uma finalidade definida, o que também gera, à sua maneira, uma impressão de circularidade.

Chico Buarque, assim como Raduan Nassar, faz da literatura uma forma de expressão essencial. Sua carreira artística é respeitável e já integra a história cultural do Brasil. Começou como compositor e cantor popular, escreveu peças teatrais e, por fim, passou a se dedicar predominantemente à literatura, logrando conquistar seu espaço no cânone contemporâneo. Embora tenha escrito a novela Fazenda modelo em 1974, é com Estorvo (1991) que começa a ser percebido como escritor. Na variedade de sua obra, destaca-se como traço comum o compromisso com a temática social e política. De "Pedro, pedreiro" a Leite derramado, passando por Os saltimbancos e Ópera do malandro, manteve sempre a preocupação de denunciar e combater a opressão e a desigualdade social. Esse engajamento, bastante explícito na produção anterior, aparece matizado em seu primeiro romance. E é nesse sentido que interessa aproximálo aqui do livro de Raduan Nassar.

O narrador, cujo nome permanece oculto, acorda com alguém tocando a campainha. Temendo o desconhecido por alguma razão que não fica clara, ele o despista e foge. Procura a irmã, que mora em uma rica mansão, recebe dinheiro dela e segue para o antigo sítio da família. Como este se encontra ocupado por pessoas suspeitas, acaba se dirigindo ao local de trabalho da antiga esposa, que lhe fornece a chave de sua casa para que apanhe a mala com sua roupa. Continua a perambular, retornando à casa da irmã, onde se aproveita da festa que lá acontecia e rouba todas as joias, que são passadas aos novos habitantes do sítio, para onde acaba voltando em busca de refúgio. Em troca das joias, recebe uma mala de maconha que tenta deixar, primeiro, no apartamento da mãe e, depois, no do amigo, mas a mala se abre ao despencar escada abaixo e ele tem de fugir. Depois de estilhaçar a vidraça da loja em que trabalha a exmulher, é levado novamente para a casa da irmã, e aí fica sabendo do assalto e do estupro 
sofrido por ela. Acompanha o delegado ao sítio, assiste à morte dos bandidos e, ao sair dali, tenta abraçar um desconhecido que o esfaqueia.

Nesse movimento, destaca-se no livro o espaço, que é associado à constante mobilidade da personagem central. Esta percorre diversos locais da cidade, culminando com dois extremos: o condomínio de luxo em que reside a irmã e o sítio da família, em que vivem, além dos familiares humildes do antigo caseiro, marginais conluiados com a polícia. Aqui, como no livro de Raduan Nassar, as personagens não têm nome e são caracterizadas à maneira de "clones publicitários", segundo a expressão de Roberto Schwarz (1999, p. 181). Essa caracterização sumária das personagens contrasta com a precisão com que é descrito o mundo externo, o que acentua um aspecto particular do narrador. Embora ele seja apresentado de forma imprecisa, é seu olhar que vai criando a perspectiva geral e o efeito do livro.

Como resultado desse procedimento, adquire relevância a atitude do narrador ao descrever os percalços de sua aparente fuga, pois não se sabe ao certo se ele é ou imagina ser perseguido. Da mesma forma que suas ações não têm sequência e ficam inconclusas, sua condição social também é pouco definida: pode ser "um joão-ninguém ou um filho-família desgarrado" (Schwarz, 1999, p. 179). Isso justifica seu trânsito por diferentes espaços, que remetem a correspondentes níveis sociais, praticando atos aparentemente sem finalidade e se mostrando indiferente a suas consequências. Sob essa perspectiva, sua movimentação vai compondo um percurso circular, acentuado pela técnica narrativa, que não estabelece claramente a distinção entre imaginação e realidade, pois o que a personagem efetivamente vive e o que considera plausível compõem esse percurso. Como este não é explicado, seu sentido pode ser buscado em sua própria condição de personagem, que encampa, assim, toda a carga significativa do título do romance: estorvo.

Ao observar o comportamento geral da personagem, Roberto Schwarz interpreta: "esta disposição absurda para continuar igual em circunstâncias impossíveis é a forte metáfora que Chico Buarque inventou para o Brasil contemporâneo" (Schwarz, 1999, p. 181). A metáfora, evidentemente, pode ser acompanhada em seus possíveis desdobramentos. De certa forma, representa a própria configuração social, em sua diversidade de categorias, que torna sutil a separação entre classes sociais. Mesmo assim, a questão das classes aparece como problema, seja nas contradições que engendram, seja no posicionamento da personagem em relação a elas. Embora não se trate propriamente de classes sociais, mas de pessoas que convivem naquela sociedade de forma um tanto promíscua, em que a irmã flerta com o delegado, este é próximo dos bandidos, os trabalhadores produzem mercadoria suspeita etc., a contradição social reponta em cada passagem. A origem do narrador, por exemplo, é fortemente sugerida. Além da posição social elevada, fica-se sabendo que o pai fora militar e, como proprietário, "tinha talento para gritar com os empregados" (Hollanda, 1991, p. 26). Sem contar que era dotado de outras qualidades inerentes, como o racismo: ao ver o porteiro ouvindo rádio, "disse que nunca se viu empregado ligar para astrologia, ainda por cima crioulo, que nem signo tem" (Hollanda, 1991, p. 92). Nesse quadro, o narrador chega a manifestar certa solidariedade por classes sociais inferiores, mas, diante da falta de clareza da linha que separa as diferentes categorias sociais, ele resta desfigurado enquanto agente político, sem rumo, sem identidade - um estorvo, enfim.

Aqui cabe a pergunta: estorvo para quem, se prevalece a indistinção entre classes, bem e mal etc.? Seria para a classe dominante ou para os pobres? A rigor, seria para sua classe de origem. Recorde-se que, além do tratamento que recebe da irmã e da ex-mulher, que mais do que ajudálo, querem se livrar dele, o cunhado sempre se refere a ele como coisa. Numa de suas idas à casa da irmã, o narrador relata: "Meu cunhado me alcança com o amigo grisalho, a quem me apresenta dizendo 'é esse'. O grisalho diz que é sempre assim, que em toda família que se preze existe um porra-louca" (Hollanda, 1991, p. 57). É a mesma forma com que o apresenta mais tarde ao delegado de polícia: "é esse" (Hollanda, 1991, p. 126). Por outro lado, há elementos que colocam o estorvo na outra ponta social. Quando se acompanha o próprio narrador e aquilo que ele representa, com sua individualidade rarefeita e relativizada diante do cenário social, desajustamento familiar ou social pura e simplesmente talvez seja pouco para definir sua condição atual, pois a configuração da personagem parece encobrir dramas mais profundos. 
Essa hipótese pode ser fundamentada em pequenos indícios fornecidos pelo narrador, que se mostra uma personagem desgarrada de sua classe, sim, mas num sentido que poderia ir além da simples rebeldia. No capítulo 6, quando recorda a convivência com seu amigo, vêm à tona fragmentos de discussão política, com implicações nas escolhas de cada um:

O álcool que levava o meu amigo para o lado da poesia também podia atacar seus nervos, deixá-lo agressivo. Era noite, e já estávamos jantando na varanda quando ele decidiu que eu era um bosta, sem mais nem menos. Disse assim mesmo: "você é um bosta". E disse que eu devia fazer igual ao escritor russo que renunciou a tudo, que andava vestido como um camponês, que cozinhava seu arroz, que abandonou suas terras e morreu numa estação de trem. Disse que eu também devia renunciar às terras, mesmo que para isso tivesse de enfrentar minha família, que era outra bosta (Hollanda, 1991, p. 78).

E o narrador prossegue relatando o discurso do amigo, que ataca a lei vigente e os governos e, passando do discurso à ação, começa a atirar coisas para fora da varanda, o que "acabou juntando o povo do sítio para ver. Ele gritava 'venham os camponeses', e os camponeses que vinham eram o jardineiro, o homem dos cavalos, o caseiro velho e sua mulher cozinheira, mais os filhos e filhas e genros e noras dessa gente, com as crianças de colo" (Hollanda, 1991, p. 78). Depois o amigo sossegou, subiram no carro dele, "um rabo-de-peixe caindo aos pedaços", e foram embora do sítio.

Na sequência, o narrador informa como conheceu sua ex-mulher, hoje uma empregada de loja de shopping. No mesmo dia da discussão com o amigo, ambos vão a uma festa de antropólogos que comemoram a formatura numa cobertura de uma praia carioca, ocasião em que ele é apresentado à mulher. As implicações desse encontro, com indícios de uma relativa decadência social e política, ficam de certa forma indicadas na observação feita pelo amigo:

Quando meu amigo me deixou em casa, ainda me lembro dele dizendo que não achou grandes coisas, a antropóloga. Eu não discuti, nunca discuti com ele. Mas antes de dormir fiquei pensando que ele podia às vezes não estar com tanta razão. Casei com a antropóloga no mês seguinte, vivi trancado com ela quatro anos e meio, e nunca mais soube do meu amigo (Hollanda, 1991, p. 79).

Após essa passagem, há um corte, seguido de um relato que ilumina algumas implicações do percurso da personagem. Para isso, é preciso considerar que, entre os espaços percorridos pela personagem, o sítio decadente da família parece representar uma espécie de núcleo simbólico. Antes local de veraneio da família abastada, é agora espaço perigoso, marcado por transações espúrias e onde o narrador busca refúgio. Curiosamente, o sítio é cenário de fatos significativos da história, tanto quando os amigos travam a conversa acima relatada, como no desfecho, com a atuação da polícia. Dessa perspectiva, há um detalhe que não passa despercebido ao leitor preocupado com o sentido político do percurso da personagem. Logo depois de recordar a discussão política com o amigo, o narrador narra um episódio aparentemente banal naquele espaço: a tentativa do velho caseiro de enxotar dois sapos que estavam no leito da piscina vazia. Enquanto o sapo mais novo, situado "na parte rasa, pula insistentemente, bate com as patas nas paredes", mas não atinge a borda, o sapo gordo "já sabe que não adianta pular para lado nenhum". Ele acompanha os movimentos do caseiro, que pisa no chão de limo da parte mais funda, onde caíra também o sapo menor.

O velho apanha o sapo gordo e o arremessa longe. Enquanto isso, o sapo menor pulou para o raso e recomeçou a dar com as patas nas paredes. O velho sobe a rampa de joelhos e vai de cócoras atrás do sapo menor. Quando está para agarrá-lo, este dá o salto impossível e atinge a borda. Logo depois, porém, como deslumbrado com seu recorde, salta de costas, revertendo a parábola. O velho agarra o sapo no ar e o atira na copa de uma mangueira (Hollanda, 1991, p. 79).

"Parábola", na verdade, é a história da caça aos sapos. Ela está cheia de sugestões simbólicas, desde a piscina inútil no sítio decadente até o destino final dos dois sapos. Após a leitura de Um copo de cólera, com a simbologia da chácara que serve de refúgio para a personagem central, é tentador estabelecer a comparação entre os dois espaços: um, apenas ameaçado; outro, 
plenamente ocupado. Mais curioso, porém, é como a imagem dos dois sapos reverbera no casal que se digladia no romance de Nassar: ela, mais jovem e defensora da ação política; ele, mais velho, desiludido e recolhido na chácara. O que interessa, porém, é a diferença entre os dois "sapões": enquanto o primeiro ainda está enfurecido com a situação, o segundo já está tranquilo, cônscio da inutilidade de lutar: "O sapo gordo parece mesmo conhecer o velho, pois agora ergue $o$ lombo e infla a cabeça, que dobra de tamanho" (Hollanda, 1991, p. 79). Num caso, observa-se o conflito interior entre o possível militante político experiente que se desencanta e deixa de atuar, mas é atingido dramaticamente pela vida exterior; no outro, o narrador pode ser projetado no sapo gordo, que não reage à ameaça iminente, que acaba por tirá-lo da piscina e jogá-lo longe.

Sinalizações como essas não são exaustivas no romance, mas aparecem o suficiente para catalisar seu sentido geral. No quadro de indefinição das personagens, das ações inconclusas, das idas e vindas desnorteadas enfim, que culminam com o desfecho sem explicação, pistas dessa natureza podem conduzir a uma possível explicação do mistério que vai envolvendo o leitor. Por isso, a passagem acima é plena de sugestões na linha de interpretação aqui proposta. Os amigos discutem poesia e, quando a tensão aumenta - no caso, em decorrência do álcool -, enveredam pela política, questionando sua própria condição social. $\mathrm{O}$ ataque à família, à ordem vigente $\mathrm{e}$ principalmente à falta de decisão de ambos para tomar partido de uma classe subalterna, representada aqui pelos "camponeses", aponta claramente para o desejo de transformar o desajuste em engajamento. Só que esse engajamento já está comprometido de saída pela sua inadequação, conforme a visão desfigurada dos camponeses enquanto classe social objeto de solidariedade política, e pode também ser visto como farsa pela parábola dos sapos na piscina.

Como se observa, indefinições e incertezas parecem caracterizar não apenas as personagens como suas próprias ações, que vão da gratuidade ao voluntarismo. Do ponto de vista da técnica literária, o procedimento narrativo desenvolve-se à maneira da imagem inicial do romance, quando a personagem observa seu suposto perseguidor através do olho mágico: "Vou regulando a vista, e começo a achar que conheço aquele rosto de um tempo distante e confuso. Ou senão cheguei dormindo ao olho mágico, e conheço aquele rosto de quando ele ainda pertencia ao sonho" (Hollanda, 1991, p. 11). O olho mágico funciona, assim, como a mediação entre a personagem e a realidade. $\mathrm{O}$ instrumento de segurança que, em princípio, resguarda a intimidade de quem está no interior de um apartamento, assume nesse caso dupla direção e, supostamente, revela o outro lado, colocando em risco a personagem que, de observadora, torna-se observada:

Mas enquanto estou ali ele não toca a campainha, não olha o relógio, não acende um cigarro, não tira o olho do olho mágico. Agora me parece claro que ele está me vendo o tempo todo. Através do olho mágico ao contrário, me vê como se eu fosse um homem côncavo. Assim ele me viu chegar, grudar o olho no buraco e tentar decifrá-lo, me viu fugir em câmera lenta, os movimentos largos, me viu voltar com a fisionomia contraída e ver que ele me vê e me conhece melhor do que eu a ele (Hollanda, 1991, p. 12).

A perspectiva do olho mágico deforma a realidade, permitindo misturar aspectos objetivos à imaginação ou sonho. O próprio sujeito que toca a campainha pode integrar esse universo onírico. Mas, como o narrador dirá no capítulo 4, "a curiosidade é mesmo feita do que já se conhece com a imaginação" (Hollanda, 1991, p. 58). Essa combinação do experimentado com o imaginário alimentando a curiosidade é, talvez, a responsável pela movimentação sem destino da personagem. Com isso, sua busca vai-se revelando vazia, sem objetivo definido, servindo principalmente para configurar o percurso circular, em que o indivíduo fica ao sabor de acontecimentos aleatórios e alheios a seus desígnios, até ser ferido pela lâmina do desconhecido da camisa quadriculada que ele tentara abraçar. O desfecho engata, dessa forma, com o início, em clima igualmente onírico, a não ser pela mancha de sangue na camisa, que parece real. Depois de ser esfaqueado, toma o ônibus que vai para a cidade e começa a imaginar as pessoas que poderão acolhê-lo: a mãe, para quem pretende ligar; a irmã, de quem espera ajuda quando ela retornar de viagem; o amigo, que poderá hospedá-lo enquanto a irmã não chega; a ex-mulher, que, ao ver a mancha viva em sua camisa, "talvez faça uma careta e [o] deixe passar" (Hollanda, 1991, p. 141).

O fim do percurso da personagem instaura uma espécie de anticlímax, já que não se esclarecem as razões de sua movimentação nem sua real condição física após o ferimento. Mas 
isso pouco importa, pois tudo pode não ter passado de imaginação do narrador, cuja razão para narrar parece mesmo ter sido a de representar algo inútil e sem sentido aparente. Uma espécie de Odradek kafkiano: "Seria o caso de se acreditar que este objeto, outrora, tenha tido alguma finalidade, que agora esteja apenas quebrado. Mas ao que parece, não é o que se dá; ao menos não há sinal disso; não se vê marca alguma de inserção ou de ruptura, que indicasse uma coisa destas; embora sem sentido, o todo parece completo à sua maneira" (Kafka apud Schwarz, 1978, p. 21-2). Vem possivelmente de detalhes desse tipo a força do livro de Chico Buarque, que elabora uma personagem capaz de representar o impasse político dos anos posteriores à ditadura militar, menos pelo relato de fatos e dramas do que pelo trabalho com a linguagem.

\section{Impasse}

Na linha de força apontada no início, constituída pelos romances S. Bernardo, Um copo de cólera e Estorvo, observa-se, do ponto de vista da representação do embate político no Brasil do século XX, uma sequência de angústia, cólera, perplexidade (ou desnorteio, inação). Enquanto no primeiro romance o narrador fica no impasse da escrita, sem poder avançar na compreensão da esposa morta e de sua própria condição de homem reificado, no romance de Raduan Nassar, o narrador, um chacareiro com dotes intelectuais, parece um ex-militante revoltado com os rumos da política e com o possível horizonte das mudanças, condição que o leva a um grande desabafo que pode ser entendido também como autocrítica. Já no romance de Chico Buarque, o desencanto prevalece. Como indica Roberto Schwarz, "o desejo de uma sociedade diferente e melhor parece ter ficado sem ponto de apoio", sugerindo que "a suspensão do juízo moral, a quase-atonia com que o narrador vai circulando entre as situações e as classes, seja a perplexidade de um veterano de 68" (Schwarz, 1999, p. 180).

Essas hipóteses interpretativas repousam menos naquilo que os romances aqui analisados apresentam explicitamente do que naquilo que configuram como impasse: tanto de viver como de narrar. Mas, assim como ocorre em S. Bernardo, trata-se de impasse pleno de sentido para o leitor, compreensível no efeito provocado pelo movimento das personagens, que na sua maneira de ser se expressam enquanto cólera e estorvo.

É possível que a atmosfera de inconclusão configurada nesses livros, uma espécie de sequência de impasses lastreados em contextos históricos anteriores, especialmente no da década de 1930, encontre alguma reverberação na crise política que se experimenta no início do século XXI. Não é fácil conceber com clareza as contradições vividas nesse momento, cabendo a escritores que se mantenham acima das tensões imediatas dar forma artística àquilo que atormenta quem luta por transformações sociais capazes de proporcionar melhores condições de vida a um número cada vez maior de pessoas. Pode-se, no máximo, com base em traços percebidos ao longo do século XX, especular que está em causa uma redefinição da forma de se lutar por ideais socialistas.

\section{Referências}

ADORNO, Theodor W. (1980). Posição do narrador no romance contemporâneo. In: BENJAMIN, Walter et al. Textos escolhidos. Traduções de José Lino Grünnewald et al. São Paulo: Abril Cultural. p. 269-73. (Os Pensadores).

CANDIDO, Antonio (1993). Dialética da malandragem. In: CANDIDO, Antonio. O discurso e a cidade. São Paulo: Duas Cidades.

HOLLANDA, Chico Buarque de (1991). Estorvo. São Paulo: Companhia das Letras.

LIMA, Thayse Leal (2006). O mundo desencantado: um estudo da obra de Raduan Nassar. 2006. 141f. Dissertação (Mestrado em Estudos Literários) - Universidade Federal de Minas Gerais, Belo Horizonte.

NASSAR, Raduan (1996). A conversa. Cadernos de Literatura Brasileira, São Paulo, n. 2, Raduan Nassar, p. 23-39. 
NASSAR, Raduan (1992). Um copo de cólera. 5. ed. São Paulo: Companhia das Letras.

PERRONE-MOISÉS, Leyla (1996). Da cólera ao silêncio. Cadernos de Literatura Brasileira, São Paulo, n. 2, Raduan Nassar, p. 61-77.

SCHWARZ, Roberto (1999). Sequências brasileiras: ensaios. São Paulo: Companhia das Letras.

SCHWARZ, Roberto (2012). Sobre Adorno. In: SCHWARZ, Roberto. Martinha versus Lucrécia: ensaios e entrevistas. São Paulo: Companhia das Letras. p. 44-51.

SCHWARZ. Roberto (1976). Tribulação de um pai de família. In: SCHWARZ, Roberto. O pai de família e outros estudos. Rio de Janeiro: Paz e Terra. p. 21-6.

SISMONDINI, Alberto (2017). Arabia brasílica. Tradução de Letizia Zini Antunes e Valéria Vicentini. Cotia: Ateliê.

\section{Notas}

${ }^{1} \mathrm{O}$ autor é bolsista de Produtividade em Pesquisa do Conselho Nacional de Desenvolvimento Científico e Tecnológico (CNPq), nível 2.

2 Este artigo é uma versão ampliada de trabalho apresentado na Conferência Internacional "Brasil-Itália: ida e volta. História, cultura, sociedade", realizada na Università Cattolica del Sacro Cuore de Milão, Itália, em 2016, publicado em Visioni LatinoAmericane, v. 18, p. 420-428, em jan. 2018. Esboço da análise dos romances aqui abordados integrou o estudo "Romance e política no Brasil", publicado em: VAZQUEZ, Raquel Bello et al. (Ed.). Estudos da AIL em literatura, história e cultura brasileiras. Santiago de Compostela; Coimbra: Associação Internacional de Lusitanistas, 2015. p. 25-33. 